\title{
Self-construction, work adjustment and thriving at work
}

\section{Susanne G. Scott* and Kellyann Berube Kowalski}

Charlton College of Business, University of Massachusetts Dartmouth, North Dartmouth, MA 02747, USA

E-mail:sscott@umassd.edu

E-mail: kkowalski@umassd.edu

*Corresponding author

\begin{abstract}
In this article, we review and provide a framework for understanding recent research on work adjustment. Work adjustment is defined as a process rather than an outcome, and it occurs through self-and social construction. We describe two paths to work adjustment that have been identified in the organisational literature, and we provide a third path - liminality - which has not yet received much attention in the literature. The work adjustment process has significant implications for employee well-being, as well as motivation and performance.
\end{abstract}

Keywords: management development; self construction; work adjustment; thriving at work; social construction; socialisation; issue selling; job crafting; organisational identification.

Reference to this paper should be made as follows: Scott, S.G. and Kowalski, K.B. (2011) 'Self-construction, work adjustment and thriving at work', Int. J. Management Development, Vol. 1, No. 1, pp.98-109.

Biographical notes: Susanne G. Scott received her PhD in Management from the University of Cincinnati and is currently the Associate Dean and an Associate Professor of Management at the Charlton College of Business. Her research focuses on individual and organisational identity and the scholarship of teaching and learning. Her research has appeared in numerous scholarly journals, including Organizational Behavior and Human Decision Processes, Academy of Management Review, The Academy of Management Journal, Personnel Psychology, and the Journal of Management Education.

Kellyann Berube Kowalski is an Associate Professor of Management at the Charlton College of Business. She received her PhD in Management from the University of Rhode Island and MBA from Northeastern University. Her research interests lie in the area of role theory, with specific interests in balancing work and family roles, managing diversity, and telecommuting. She has done research on the role that social support plays in buffering the effects of work-family conflict. Recently, she has become interested in how telecommuters deal with the lack of boundaries between their work and family roles. She teaches courses such as human resource management, organisational behaviour, and teamwork. 


\section{Introduction}

Organisations face a serious dilemma. Hyper-competition, global economic conditions, and rapid technological change have created increasing demand for flexibility in human assets. To a large degree organisations meet this challenge by renegotiating the employment contract, transforming employees into free agents through outsourcing, downsizing, and the use of short term contracts and temporary workers. As a result, stable jobs are becoming relics of the past (e.g., Arthur and Rousseau, 1996b; Hall, 1996) and individual careers are discontinuous. Ironically, the macro-conditions driving discontinuity in employment also create unprecedented demand for productivity gains, which largely rely on improved employee performance and organisational citizenship. Organisations require employees that hit the ground running, accelerate their pace quickly, and demonstrate the myriad behaviours that we have come to expect from committed employment relationships (e.g., loyalty, innovation) despite little expectation of a long term stay.

The questions raised by this context are straight-forward:

1 How can organisations help new employees get up and running quickly?

2 What motivates high in-role performance and citizenship behaviour in the absence of long-term employment expectations?

Traditionally, organisational researchers have focused on socialisation (Jones, 1986; Van Maanen and Schein, 1979) as a means through which newcomers are nurtured to move from outsider to a productive role as an organisational member. Socialisation has been defined as the process through which individuals acquire the attitudes, behaviour, and knowledge they need to participate as organisational members (Van Maanen and Schein, 1979; Jones, 1986). The socialisation literature traditionally focused on the tactics organisations use to influence employees' perceptions, behaviours, and sense-making (Saks and Ashforth, 1997). Morrison (2002) notes that socialisation includes "an organization attempting to mold new employees to fit its needs and (emphasis added) employees attempting to define an acceptable role for him- or herself within the organization" (p. 1149).

Alternatively, the role transition literature (e.g., Nicholson, 1987; Louis, 1980; Saks and Ashforth, 1997) attempts to explain the psychological experience of role entry and employee meaning-making processes. This literature, drawing from the rich perspective of role theory, gives the individual a more central position than the socialisation literature. Yet, neither literature views new employees as active players in determining the features, requirements, and meaning of their jobs, roles, and/or organisations.

In the last decade, the focus of the work adjustment literature has moved toward a view of newcomers as co-conspirators in the writing of their own saga. We now view work adjustment, performance, and citizenship following job or organisational entry as well as numerous other outcomes as shaped by the meaning employees attribute to their work (Gergen, 1994; Salancik and Pfeffer, 1978) and by how they define themselves at work (Bartel and Dutton, 2001; Pratt, 2000). Thus, as newcomers construct and enact their roles, jobs, and/or organisations, they construct and enact their own identities. To the extent that they are able to create positive overlap between how they define themselves and how they define their work and/or their organisations, their work identification and/or organisational identification increases (Pratt, 1998; Dutton et al., 
1994; Scott and Lane, 2000). From this social-constructivist perspective (Gergen, 1994), individual work adjustment is viewed as the complex and dynamic process through which individual identity, the identity of the work, and the identity of the organisation are contested and negotiated through iterative interactions over time.

We begin this article by briefly reviewing prior theoretical work on organisational socialisation with particular attention to how the individual has been conceptualised in the extant literature. In the next section, we introduce a framework for understanding individual work adjustment that integrates current developments in identity theory. Then we discuss anticipated attitudinal and behavioural outcomes, and possible context moderators. We finish by examining the relevance of this approach for the management of today's employees.

\section{Socialisation and work adjustment}

Two thorough reviews of the socialisation literature were published in the late 90's (Ashforth and Mael, 1989; Ashforth and Saks, 1996; Bauer et al., 1998; Saks and Ashforth, 1997), and we will not attempt to restate these here. Research largely has focused on socialisation tactics leading to the conclusion that "the potential of cognitive and sense-making theory to inform our understanding of socialization is vast" but "the process of sense-making has not been a central focus of previous research" [Saks and Ashforth, (1997), p.238].

There has been an exciting trend in socialisation research during the last decade from a view of newcomers as vessels to be filled to one of proactive learners. Yet, proactivity is still largely defined as actively socialising oneself and the underlying bias is that work adjustment means employees conform to socialisation tactics or they leave. This ideology appears appropriate for the types of newcomers focused on in research to date (e.g., army recruits, recent graduates, entry-level accountants). However, there is mounting evidence that this type of job or organisational change represents a small percentage of the total in today's workplace. People are now changing jobs an average of eight times in their working lives; seven of those changes will clearly be as veterans with more welldeveloped self-concepts, more experiences, knowledge, and ideas to bring to the new workplace. Understanding the work adjustment processes of veteran newcomers as well as those of new graduates requires a theoretical model that specifies how individuals impute meaning to their work, come to know their work identities, and improvise in order to find a correspondence between their jobs, their organisations and themselves. Extant theory fails to adequately explicate the process of work adjustment for those who change jobs at mid- or late career (Bauer et al., 1998; Saks and Ashforth, 1997).

\section{Work adjustment through mutual accommodation}

Figure 1 depicts a model of individual work adjustment. Newcomer work adjustment begins at the point in time that newcomers accept membership in an organisation (i.e., they take the job) and ends at the point in time that they are identified with their work role and their employing organisation or they leave the job. However, we note that this is, in fact, only the first cycle in the dynamic iterative process of employee work adjustment. With each successive change in context within the organisation, the cycle repeats itself. 
Figure 1 Paths to work adjustment of newcomers (see online version for colours)

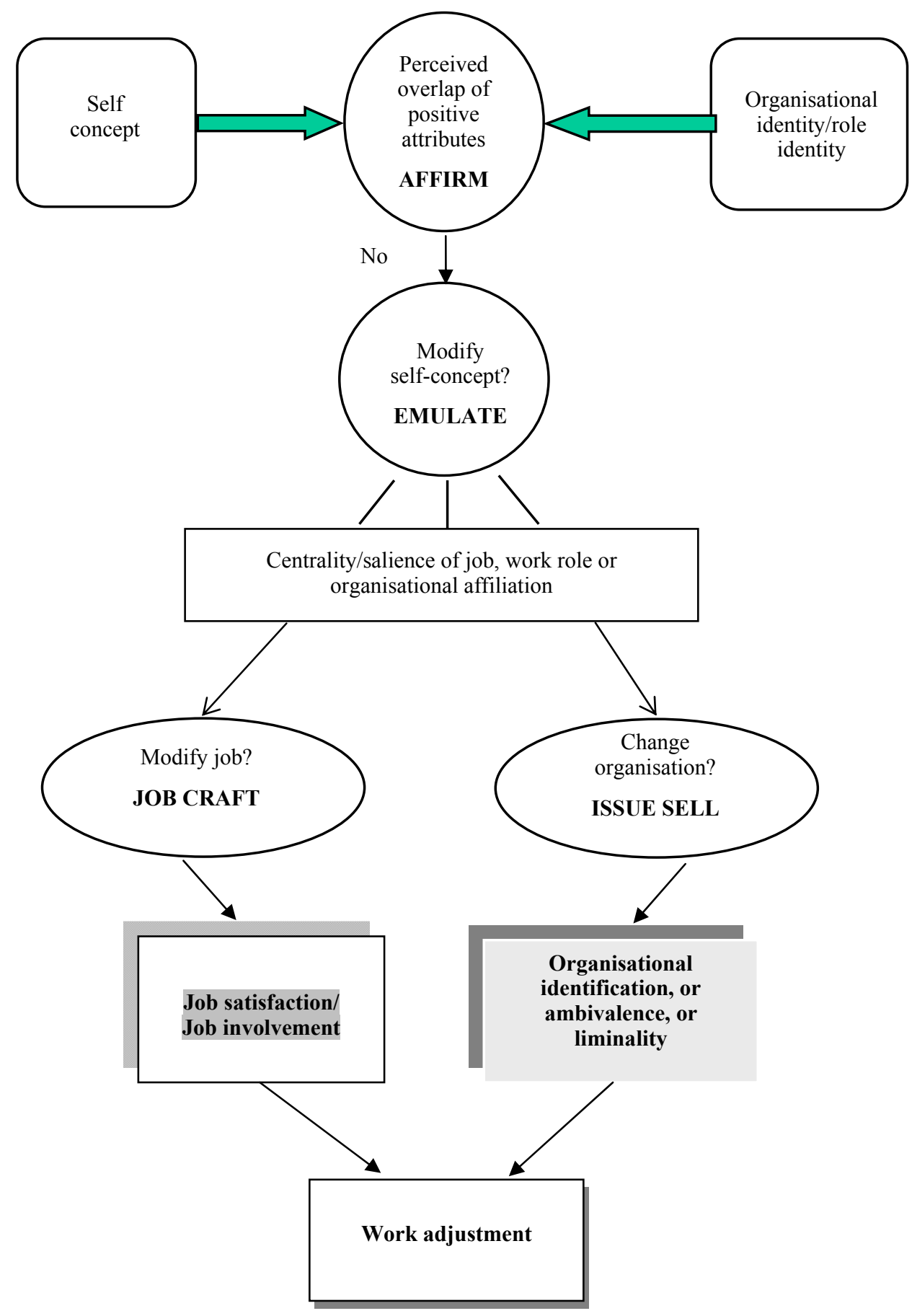




\subsection{Role and/or organisational entry}

Job seekers search for positions in which they perceive an overlap of valued aspects of the self with features of their role and organisation (Kristof, 1996). Yet, in one of the few studies attempting to find support for this relationship, perceived P-O fit was unrelated to job choice decisions (Judge and Cable, 1997). Perceived P-O fit is only one of many job attributes applicants weigh in the complex decision to accept a job; others include pay, company reputation, anticipated co-workers and supervisor, and location. Job seekers weigh these attributes in the context of labour-market conditions and their other role commitments (e.g., spouse and family needs). Because both individuals and organisations have multi-dimensional identities, it is also possible that there is a perceived fit on certain identity dimensions and a lack of fit on others.

Even when job seekers place their highest priority on achieving P-O fit, they can have great trouble making an accurate assessment of it. During the pre-entry experiences of recruitment and selection, recruiting organisations often use impression management tactics to encourage applicants to develop a favourable (rather than accurate view of their culture), making accurate assessments of P-O fit difficult for job seekers.

\subsection{The attractiveness of the role and/or organisational identity}

Once applicants become newcomers, they begin the process of socialisation in earnest. Obviously, organisations have identities that are central and important to who they are (e.g., innovative, family-oriented). Through socialisation processes, an organisation tries to influence newcomers to value that identity as their own. The degree of perceived correspondence between newcomers' identities and an organisational identity at entry may vary considerably because of tradeoffs made in the job search stage or because of the difficulty of accurate assessment of organisational identity prior to entry.

During socialisation, newcomers are introduced to the organisation's views on performance proficiency, politics, language, people, goals/values, and history (Chao et al., 1994). Newcomers encounter their new role identity and organisation identity either in formal training or in the tasks they are asked to perform. They interpret a work role identity [i.e., "goals, values, beliefs, norms, interaction styles, and time horizons that are typically associated with their role" (Ashforth, 2001)] and an organisational identity [i.e., the central, distinctive, and enduring attributes of the organisation (Albert and Whetten, 1985; Dutton and Dukerich, 1991; Dutton et al., 1994)] through the lens of their prior experiences and professional and alternative work identities (Pratt et al., 2001). They struggle to make the new role identity and organisational identity a viable fit with their ideal role identity and organisational identity, which by definition have meaning for them.

As newcomers interpret and construct their new social identity, they assess fit to their own needs, values, beliefs, and goals and subsequent attractiveness of the work role. Researchers have shown that this assessment results in one of three possible outcomes (Pratt, 1998; Pratt and Rosa, 2003). Affinity is said to exist when a newcomer seeks out an organisation based on its perceived similarity with the newcomer's own identity; that is, she finds the new organisational identity attractive (Schneider, 1987), strongly identifies with the organisation, and seeks interaction with the organisation (Dutton, et al., 1994). For affinity to occur, a job-seeker must have a well-developed sense of their 
own identity, have adequate time and resources to search for a match, and make an accurate assessment of the organisational identity prior to hire.

In contrast to affinity, emulation involves a newcomer changing existing value and belief systems, change that is often induced by organisational influence (Pratt, 1998). Emulation occurs when newcomers encounter a role or organisational identity that is incongruent with their personal identity. Despite this, the newcomer chooses to take on the beliefs and values of the role and organisation, and construct a new social identity.

To some degree, all newcomers are pre-disposed to think positively of their new job and new employer and to emulate their identity because of self-consistency needs (Festinger, 1957; Heider, 1958; Steele, 1988) across situations and across time. In addition, once newcomers have chosen to join an organisation, they can rationalise this behaviour by retrospectively attributing positive attributes to the organisation and to their job and by bringing their self-concept into congruence with their perceptions of their work role and organisation (Steele, 1988; Staw, 1980). To the extent that their job choice was voluntary, they would have an even greater incentive to do so.

Obviously, emulation is not always successful. Even for those who are motivated to seek new social identities, sense giving efforts by the organisation sometimes fail to provide meaningful social identities, in which case newcomers are thought to disidentify (i.e., active repudiation of the identity) or ambivalently identify (i.e., remain psychologically attached and unattached at the same time) (Pratt, 2000).

There are other routes to identification that have only recently begun to garner research attention - job and issue selling. These routes are particularly likely when a newcomer is a veteran. Veterans' self-identities are more likely to be well elaborated, tightly interconnected, and interwoven within the self-schema (Scott and Lane, 2000; Lane and Scott, 2007). Thus, their ideal role and ideal organisation are more accessible and salient in their cognitive structures.

\subsection{Job/role crafting}

Job crafting - involves the newcomer proactively crafting her work to change its meaning, thus making it more attractive. Wrzesniewski and Dutton (2001, p.180) define job crafting as "the actions employees take to shape, mold, and redefine their jobs" and "a creative and improvised process that captures how individuals locally adapt their jobs in ways that create and sustain a viable definition of the work they do and who they are at work".

The motivation to engage in job crafting is control over the workplace, to modify jobs that do not contribute positively to newcomer self-image (e.g., Ashforth and Kreiner, 1999), and/or to forge relational connections with others as a way to introduce meaning (Baumeister and Leary, 1995). Relative to the control motive, Gecas (1986, p.140) noted that self-perception has at its core "the experience of agency". The amount of perceived control is positively related to a sense of psychological ownership, and the target of successful control efforts "becomes part of the psychological owner's identity" [Pierce et al., (2001), p.299]. Thus, employees seek control of their work roles and organisations to establish psychological connection with them. Consistent with this, Ashforth and Saks (2000) found that the perceived control of newly graduated business students was related to their organisational identification.

To change the cognitive meaning of a role, Ashforth and Kreiner (1999) suggested that employees engage in: 
1 reframing (i.e., expressing the particulars of a role in abstract, positively value-laden terms)

2 neutralising (i.e., deflecting responsibility by denying volition of action), recalibrating (i.e., magnifying the value of tasks to achievement of some higher good), and refocusing (i.e., disattendance to problematic aspects of the task).

The literature provides ample evidence of employees' ability to interpret their tasks in ways that preserve their self-esteem (e.g., Dutton et al., 1996; McIntyre, 1987; Palmer, 1978; Rollins, 1985).

Crafting attempts may fail. Individuals may find that they cannot sustain the cognitive dissonance created by the mismatch between their beliefs and their actions. They may actively work on role performance but find moments of insight when they 'realise' that 'the emperor has no clothes'. Research suggests that this results in disidentification or ambivalence. Disidentification generates intentions to leave active job search activity and actual turnover. There is likely to be urgency in this process. If opportunities to change jobs or roles are scarce, disidentification may result in behaviours meant to thwart role/organisation objectives: resistance, aggression, sabotage (Dukerich et al., 1998). Organisations are likely to react with disciplinary action and in the extreme with termination.

Ambivalence is defined as "simultaneous and contradictory attitudes or feelings...toward an object, person, or action" or "continual fluctuation (as between one thing and its opposite)" (Merriam Webster's Collegiate Dictionary, 2008). It is most typically seen as a pathological state, an unstable condition in which an employee experiences great stress and dissonance (e.g., Dukerich et al., 1998), what has been called a 'struggle' (Pratt, 2000). Ambivalence would appear to be the most emotionally difficult state of work adjustment for employees.

\section{$3.4 \quad$ Issue selling}

The final path that we identify for newcomers to adjust to their work role or organisation is through issue-selling. Newcomers who do not respond to sense giving, and that fail to construct a viable role/organisational identity through crafting, often engage in actions that promote organisational change. They issue-sell in order to transform the role/organisation into one that provides a better fit for their needs, values, and beliefs.

Issue selling refers to behaviours that are directed toward affecting others' attention to and understanding of issues [Dutton and Ashford, (1993), p.398]. It is a political action characterised by lobbying to achieve one's desired ends, that is, to preserve and defend one's self-concept in an environment that does not support it (Creed and Scully, 2000; Harquail, 1996). It is a voluntary, discretionary behaviour engaged in the motivation of persuading those in control to pay attention to issues of importance to the issue-seller. For the most part, issue-selling has been studied in the context of mid-level management (issue-selling to influence which events, developments, and trends, top-level managers pay attention to, and thus what becomes defined as a strategic issue) (Dutton and Ashford, 1993; Dutton et al., 2001), the selling of gender-equity issues (e.g., Ashford et al., 1998), and lobbying for same-sex partners' health benefits (Creed and Scully, 2000) by managers. But issue-selling can occur at any level in the organisation when an issue is important to the issue-seller; the issue-seller sees the issue as relevant and important to the organisation; and the issue overlaps with an alternative identity held by an issue-seller 
(Harquail, 1996; Ashford et al., 1998). This suggests that issue-selling occurs when an issue has identity-relevance to a potential issue-seller. Issue-selling is a behaviour through which newcomers whose self-definition is incongruent with their organisation lobby to engage the attention of powerful others and make change happen.

Issue-selling is most likely when an issue is viewed by the seller as highly important to their self-concept, and subsequently to the organisation that partly determines their self-concept (Harquail, 1996). In addition, various contextual cues influence the willingness of people to issue-sell (Ashforth et al., 1998; Dutton et al., 1997). Here, we suggest that liminal status is an important precursor to issue-selling. Liminality is a path least explored in the organisational literature, but one that is common and that has a significant effect on individual identity processes (Turner, 1967, 1974).

Van Gennep (1960) addressed the liminal stage of a rite of passage as the point at which an individual has let go of a prior identities but not yet cleaved to a new one. In this sense, liminality is a temporary condition as a person transitions from one identity to the next, yet the transition can be an extended period of time (e.g., adolescence). More recently, ideas of liminality as an ongoing condition have been introduced (Turner, 1974). Liminal people are not in nor are they out (Turner, 1967); they are at the party but not of it. They are excluded from the disidentified and from the identified, and placeless in the sense of having no established identity group.

In the organisational literature, researchers are only beginning to attend to liminality as jobs and careers become more fluid, and people spend more of their time in luminal spaces (Czarniawski and Mazza, 2003; Garsten, 1999; Hochschild, 1997; Paulsen and Hernes, 2003; Tempest and Starkey, 2004). While liminality has traditionally been understood as emotionally draining and stressful, evidence is beginning to emerge that people are capable of choosing luminal identities and thriving.

“...liminality is not necessarily to be avoided. To be betwixt and between enables freedom of movement and a type of flexibility generally foreclosed to people with firmer identities. In fact, Turner argued that the condition of liminality generated creativity and openness to learning." [Zabusky and Barley, (1997), pp.370-371]

Zabusky and Barley's (1997) ethnography of staff scientists in the European Space Agency clearly demonstrates that some employees thrive on their liminal status. They note that it may be the experience of liminality, "the experience of being between, rather than part of, all the groups that are available for the construction of identity" [Zabusky and Barley, (1997), p.392] that permits issue-selling, whistle-blowing, and other types of challenge to the organisational status quo.

Other studies are beginning to emerge showing that liminal spaces, while initially unsettling, become increasingly familiar and comfortable with experience (Sturdy et al., 2006). Such spaces seem particularly important in consultancy practices (Czarniawska and Mazza, 2003), and, more particularly, in the very top of organisations where work life and home life often merge (Marshall, 2003).

As poetically stated by Turner (1979, p.41), liminality is "an instant of pure potentiality" because liminality is by definition the lifting of social constraints, emancipation from the structures that bind. Liminal employees may represent those in organisations who can see the forests for the trees. To a certain extent, being able to discern that change is needed in a system or subsystem requires stepping outside the system and looking back in. At the extreme, socialisation can be viewed as the process 
through which individuals are immersed in a cultural milieu and embedded so thickly in the social system that they lose other referents or standards. In fact, identification, by definition, occurs through the psychological acceptance of a collective's culture, and identification is most often viewed as positive work adjustment. But, liminal employees, whether committed to the mission or task of the organisation or job, understand themselves to be at the interface of conjoined systems and maintain clarity of vision. Liminal employees balance the needs of the various roles, both work and non-work, that they inhabit. They do not cleave to the group per se, but to the mission to which it is committed.

\section{Summary}

Current research focuses on work adjustment as a dynamic, iterative process occurring across time, not just the short period of time usually focused on in the socialisation literature. We have listed some behavioural indicators of work adjustment in Figure 1, but we do not suggest that this is an exhaustive list. More importantly, we note the feedback loops from these indicators to a subsequent role/organisational entry, which are ever more likely in the employment climate of today. Researches on socialisation and work adjustment have largely ignored the effects of prior socialisation/work adjustment, and of the social identities that have been constructed in these prior settings. We argue that socialisation in one role/organisation cannot be understood without reference to prior identifications with work and non-work roles. Role/organisation entry cannot be understood without understanding the process of exit that preceded it.

Employers seriously underestimate the need for self-determination in newcomers and employees. Newcomers will take action to change or customise their roles or organisations, for better or worse. An identity perspective, such as that taken here, focuses more clearly on a central issue that needs to be addressed - the tension between employees' needs for control and the legitimate needs of organisations for order. People construct their self-concept by not only attending to sense breaking and sense giving, organisational activities, but by actively engaging in role-crafting and issue-selling.

Both crafting and issue-selling are behaviours that go beyond the type of pro-activity discussed previously in the socialisation and role-transition literature. While we have developed a good understanding of sense giving processes, we are only beginning to seriously appreciate the actions that employees take to construct a role/organisation identity that is viable for them.

Inherent in the approach advanced here, moderate identification may be preferable to strong identification in determining employee work-adjustment. Employees live at the interface of many boundaries: those between different genders, different ethnicities, different organisations, different work roles, and work and non-work roles. They must navigate across these boundaries iteratively during a day, a month, and a year of their lives, finding a way to meet the demand of many different role sets. Priorities, norms, standards, beliefs change as boundaries are crossed, requiring flexibility in selfdefinition. Immersion in any of these alternative cultures can imply that differing selfconceptions come to the fore. Liminality may offer a way of understanding the ability to do so. 


\section{References}

Albert, S., and Whetten, D.A. (1985) 'Organizational identity', in Cummings, L.L. and Staw, B.M. (Eds.): Research in Organizational Behavior, Vol. 8, pp.263-295, JAI Press, Greenwich, CT.

Arthur, M.B., Rousseau, D.M. (1996) 'Introduction: the boundaryless career as a new employment principle', in Arthur, M.B. and Rousseau, D.M. (Eds.): The Boundaryless Career: A New Employment Principle For A New Organizational Era, pp.3-20, Oxford University Press, New York.

Ashford, S., Rothbard, N.P., Piderit, S.K. and Dutton, J.E. (1998) 'Out on a limb: the role of context and impression management in selling gender-equity issues', Administrative Science Quarterly, Vol. 43, pp.23-57.

Ashforth, B.E. (2001) Role Transitions in Organizational Life: An Identity-Based Perspective, Lawrence Erlbaum Associates, Matwah, NJ.

Ashforth, B.E. and Kreiner, G.E. (1999) 'How can you do it? Dirty work and the challenge of constructing a positive identity', Academy of Management Review, Vol. 24, pp.413-434.

Ashforth, B.E. and Mael, F. (1989) 'Social identity theory and the organization', Academy of Management Review, Vol. 14, pp.20-39.

Ashforth, B.E. and Saks, A.M. (1996) 'Socialization tactics: longitudinal effects on newcomer adjustment', Academy of Management Journal, Vol. 39, pp.149-178.

Ashforth, B.E. and Saks, A.M. (2000) 'Personal control in organizations: a longitudinal investigation with newcomers', Human Relation, Vol. 53, pp.311-321.

Bartel, C. and Dutton, J.E. (2001) 'Ambiguous organizational memberships: constructing organizational identities in interactions with others', in Hogg, M.A. and Terry, D. (Eds.): Social Identity Processes in Organizational Contexts, Psychology Press, Philadelphia.

Bauer, T.N., Morrison, E.W. and Callister, R.R. (1998) 'Organizational socialization: a review and directions for future research', in Ferris, G.R. (Ed.): Research in Personnel and Human Resources Management, Vol. 16, pp.149-214, JAI Press, Greenwich, CT.

Baumeister, R.F. and Leary, M.R. (1995) 'The need to belong: desire for interpersonal attachments as a fundamental human motivation', Psychological Bulletin, Vol. 117, pp.497-529.

Chao, G.T., O’Leary-Kelly, A.M., Wolf, S., Klein, H.J. and Gardner, P.D. (1994) 'Organizational socialization: its content and consequences', Journal of Applied Psychology, Vol. 79, pp.730-743.

Creed, D.W.E. and Scully, M.A. (2000) 'Songs of ourselves: employees' deployment of social identity in workplace encounters', Journal of Management Inquiry, Vol. 9, pp.391-408.

Czarniawska, F. and Mazza, C. (2003) 'Consulting as liminal space', Human Relations, Vol. 56, No. 3, pp.267-290.

Dukerich, J.M., Kramer, R. and McLean Parks, J. (1998) 'The dark side of identification', in Whetten, D.A. and Godfrey, P.C. (Eds.): Identity in Organizations: Building Theory Through Conversations, pp.245-256, Sage, Thousand Oaks, CA.

Dutton, J.E. and Ashford, S.J. (1993) 'Selling issues to top management', Academy of Management Review, Vol. 18, pp.397-428.

Dutton, J.E. and Dukerich, J.M. (1991) 'Keeping an eye on the mirror: Image and identity in organizational adaptation', Academy of Management Journal, Vol. 34, pp.517-554.

Dutton, J.E., Ashford, S.J., O'Neile, M.O., Hayes, E. and Wierba, E.E. (1997) 'Reading the wind: how middle managers assess the context for selling issues to top managers', Strategic Management Journal, Vol. 18, pp.407-418.

Dutton, J.E., Ashford, S.J., O'Neil, R.M. and Lawrence, K.A. (2001) 'Moves that matter: issue selling and organizational change', Academy of Management Journal, Vol. 44, pp.716-736.

Dutton, J.E., Debebe, G. and Wrzesniewski, A. (1996) 'The revaluing of de-valued work: the importance of relationships for hospital cleaning staff', Paper presented at the annual meeting of the Academy of Management, Cincinnati, $\mathrm{OH}$. 
Dutton, J.E., Dukerich, J.M. and Harquail, C.V. (1994) 'Organizational images and member identification', Administrative Science Quarterly, Vol. 39, pp.239-263.

Festinger, L. (1957) A Theory of Cognitive Dissonance, Row, Peterson, Evanston, IL.

Garsten, C. (1999) 'Betwixt and between - temporary employees as liminal subjects in flexible organizations', Organization Studies, Vol. 20, No. 4, pp.601-617.

Gecas, V. (1986) 'The motivational significance of self-concept for motivational theory', in Lawler, E.J. (Ed.): Advances in Group Processes, Vol. 3, pp.131-0156, JAI Press, Greenwich, CT.

Gergen, K.J. (1994) Realities and Relationships, Soundings in Social Constructionism, Harvard University Press, Cambridge, MA.

Hall, D.T. (1996) 'Protean careers of the 21st century', Academy of Management Executive, Vol. 10 , pp.8-16.

Harquail, C.V. (1996) 'When one speaks for many: the influence of special identification on group advocacy in organizations', unpublished $\mathrm{PhD}$ dissertation, University of Michigan.

Heider, F. (1958) The Psychology of Interpersonal Relations, Wiley, NY.

Hochschild, A. (1997) The Time Bind: When Work Becomes Home and Home Becomes Work, Metropolitan Books, New York.

Jones, G.R. (1986) 'Socialization tactics, self-efficacy, and newcomers' adjustments to organizations', Academy of Management Journal, Vol. 29, pp.262-279.

Judge, T.A. and Cable, D.M. (1997) 'Applicant personality, organizational culture, and organization attraction', Personnel Psychology, Vol. 50, pp.359-395.

Kristof, A.L. (1996) 'Person-organizational fit: an integrative review of its conceptualizations, measurement, and implications', Personnel Psychology, Vol. 49, pp.1-49.

Lane, V.R. and Scott, S.G. (2007) 'The neural network model of organizational identification', Organizational Behavior and Human Decision Processes, Vol. 104, pp.175-198.

Louis, M.R. (1980) 'Surprise and sense making: what newcomers experience in entering unfamiliar organizational settings', Administrative Science Quarterly, Vol. 25, p.226-251.

Marshall, N. (2003) 'Identity and difference in complex projects - why boundaries still matter in the boundaryless organization', in Paulsen, N. and Hernes, T. (Eds.): Managing boundaries in organizations - Multiple perspectives, pp. 55-75, Palgrave Macmillan, Houndmills.

McIntyre, L.J. (1987) The Public Defender the Practice of Law in the Shadows of Repute, University of Chicago Press, Chicago.

Merriam-Websters Collegiate Dictionary (2008) 11th ed., Merriam-Webster Publishing, NY.

Morrison, E.W. (2002) 'Newcomers' relationships: the role of social network ties during socialization', Academy of Management Journal, Vol. 45, pp.1149-1160.

Nicholson, N. (1987) 'The transition cycle: a conceptual framework for the analysis of change and human resource management', in Rowland, K.M. and Ferris, G.R. (Eds.): Research in Personnel and Human Resources Management, Vol. 5, pp.167-222, JAI Press, Greenwich, CT.

Palmer, C.E. (1978) 'Dog catchers: a descriptive study', Qualitative Sociology, Vol. 1, pp.79-107.

Paulsen, N. and Hernes, T. (Eds.) (2003) Managing Boundaries in Organizations - Multiple Perspectives, Palgrave Macmillan, Houndmills.

Pierce, J.L., Kostova, T. and Dirks, K.T. (2001) 'Toward a theory of psychological ownership in organizations', The Academy of Management Review, Vol. 26, pp.198-211.

Pratt, M.G. (1998) 'To be or not to be? Central questions in organizational identification', in Whetten, D.A. and Godfrey P.C. (Eds.): Identity in Organizations: Building Theory Through Conversations', pp.171-208, Sage, Thousand Oaks, CA.

Pratt, M.G. (2000) 'The good, the bad, and the ambivalent: managing identification among Amway distributors', Administrative Science Quarterly, Vol. 45, pp.456-493. 
Pratt, M.G. and Rosa, J.A. (2003) 'Transforming work-family conflict into commitment in network marketing organizations', Academy of Management Journal, Vol. 46, pp.395-311.

Pratt, M.G., Rock, K.W. and Kaufman, J.B. (2001) 'Making sense of socialization: how multiple social identities shape members' experiences of work', Academy of Management Proceedings, pp.A1-A5.

Rollins, J. (1985) Between Women: Domestics and their Employers, Temple University Press, Philadelphia.

Saks, A.M. and Ashforth, B.E. (1997) 'Organizational socialization: making sense of the past and present as prologue for the future', Journal of Vocational Behavior, Vol. 51, pp.234-279.

Salancik, G.R., and Pfeffer, J. (1978) 'A social information processing approach to job attitudes and task design', Administrative Science Quarterly, Vol. 23, pp.224-253.

Schneider, B. (1987) 'The people make the place', Personnel Psychology, Vol. 40, pp.437-453.

Scott, S.G. and Lane, V.R. (2000) 'A stakeholder approach to organizational identity', Academy of Management Review, Vol. 25, pp.43-62.

Staw, B.M. (1980) 'Rationality and justification in organizational life', in Staw, B.M. and Cummings, L.L. (Eds.): Research in Organizational Behavior, Vol. 2, pp.45-80, JAI Press, Greenwich, CT.

Steele, C.M. (1988) 'The psychology of self-affirmation: sustaining the integrity of the self', in Berkowitz, L. (Ed.): Advances in Experimental Social Psychology, Vol. 21, pp.261-302, Academic Press, San Diego.

Sturdy, A., Schwarz, M. and Spicer, A. (2006) 'Guess who's coming to dinner? Structures and uses of liminality in strategic management consultancy', Human Relations, Vol. 59, No. 7, pp.929-960.

Tempest, S. and Starkey, K. (2004) 'The effects of liminality on individual and organizational learning', Organizational Studies, Vol. 25, No. 4, pp.507-523.

Turner, V. (1967) 'Betwixt and between: the liminal period in rites de passage', in Turner, V. (Ed.): The Forest of Symbols: Aspects of Ndembu Ritual, pp.93-111, Cornell University Press, Itaca, NY.

Turner, V. (1974) Dramas, Fields, and Metaphors, Cornell University Press, Itaca, NY.

Van Gennep, A. (1960) Rites of Passage, Chicago University Press, Chicago.

Van Maanen, J. and Schein, E.H. (1979) 'Toward a theory of organizational socialization', Research in Organizational Behavior, Vol. 1, pp.209-264.

Wrzesniewski, A. and Dutton, J.E. (2001) 'Crafting a job: revisioning employees as active crafters of their work', Academy of Management Review, Vol. 26, pp.179-202.

Zabusky, S.E. and Barley, S.R. (1997) 'YYou can't be stone if you're cement': reevaluating the emic identities of scientists in organizations', in Cummings, L.L. and Staw, B.M. (Eds.): Research in Organizational Behavior, Vol. 19, pp.361-404, JAI Press, Greenwich, CT. 